$\$=$

\title{
Prevalence of mandibular third molar impaction pattern in a private dental clinic of Sultanpur Lodhi
}

\author{
Pushappreet Kaur \\ Dental officer, Guru Nanak Dev Dental Hospital, Sultanpur Lodhi, Kapurthala, Punjab, India-144626 \\ E-mail: kaurpushp@gmail.com
}

\begin{abstract}
Background: Mandibular third molar is the most commonly impacted tooth, and its removal is a frequently performed dentoalveolar procedure. It is important to know the prevalence rate in a particular community.

Objective: This article aims at evaluation of angulation, ramus relationship and depth of impacted mandibular third molars among patients visiting a private dental clinic in Sultanpur Lodhi.

Methodology: 150 patients presenting with 228 cases of lower third molar impaction were included within this study. IOPAR and where necessary, OPG was used for radiographic assessment. Age, sex and tooth number were recorded in each patient on a specially designed performa. Angulation was determined using winter's method whereas assessment of ramus relationship and depth was done using Pell and Gregory's method.

Results and Conclusion: The age of patients ranged from 21-43 years with mean age of 26.6 years. Males showed preponderance to mandibular M3 impaction (54\%) in our study, and right side was found more frequently involved (53\%). Radiographic assessment revealed that mesioangular impaction $(45.2 \%)$ was the most prevalent angular pattern followed by vertical, distoangular and horizontal types, and Class 2 Position A (29.4\%) most common and Class 1 Position C the least common type of impaction depth and ramus relationship.
\end{abstract}

Keywords: Angulation; Impaction; Mesioangular; Preponderance; Ramus

\section{Introduction}

Tooth impaction is a pathological condition in which a tooth fails to erupt to its normal functional position within the expected time frame, either due to lack of space, or physical barriers [Agarwal et al. 2004]. Mandibular third molar (M3) is the most commonly impacted tooth and accounts for $98 \%$ of all impactions [Padhye et al. 2013]. Different studies have reported a different prevalence rate for impaction of the mandibular M3 which varies between $16.7 \%$ and $68.6 \%$, respectively [Kaya et al. 2010]. Etiology of tooth impaction is multifactorial and can be subdivided into local and general factors. Local factors include position and size of adjacent teeth, dense overlying bone, excessive soft tissue, abnormal eruption path and inadequate dental arch length and space in which to erupt, whereas general factors may include heredity, genetic abnormality, rickets, anemia, congenital syphilis, tuberculosis and malnutrition [Hupp et al. 2008]. Removal of lower M3 is a common dentoalveolar procedure and its leading indications are dental caries, germination disorders, orthodontic problems, infection, trauma, and prevention or improvement of periodontal defects in the adjacent second molar (M2) [Peterson et al. 1998] apart from mandibular angle fracture susceptibility [Meisami et al. 2002]. Additionally, some researches also report its implication in the etiology of lower arch crowding, Temporomandibular Joint (TMJ) disorders, vague orofacial pain and neuralgias [AlmendrosMarqués et al. 2008]. M3 extraction can be performed using elevators and/or forceps, or may require a surgical intervention which is frequently associated with significant complications, most com monly dry socket, infection, swelling, trismus, paresthesia of inferior alveolar nerve [Bui et al. 2003], hemorrhage during and after surgery and rarely paresthesia of lingual nerve. In majority of cases, these problems are transient in nature but in some cases may lead to permanent sensory and functional disturbances [Blondeau \& Daniel 2007].

Classifications play a key role in completing the evaluation of M3 position and assessment of procedural challenges which further help in planning optimal surgical technique to allow easy removal, minimal morbidity, thus, avoiding any serious or permanent complications. Several classifications have been known and proposed but winter's [Winter 1926], and Pell and Gregory [Pell \& Gregory 1933] most commonly used clinically. The aim of this study is to evaluate the angulation and pattern of mandibular impacted M3 based on Winter's and Pell and Gregory classification using IOPAR and/or OPG radiographic methods, among dental patients visiting a private dental clinic in the rural area of Sultanpur Lodhi.

\section{Methodology}

This study was conducted at a private dental clinic, Guru Nanak Dev Dental Hospital in Sultanpur Lodhi, Kapurthala, Punjab, India over a period of 6 months from January 2015 to June 2015. A total of 150 patients having 228 impacted mandibular third molars were selected for the study. Approval regarding the study was obtained from the institution as well as patients. 


\subsection{Selection criteria}

Patients with age less than 20 years, maxillofacial trauma, any craniofacial anomaly or syndrome (Down syndrome or Cleidocranial Dystosis), presence of incomplete data or poor quality of IOPAR/OPG, incomplete formation of root, chief complaint unrelated to impacted third molar (or associated pathologies) and absence of adjacent second molar were excluded.

\subsection{Data variables}

An individual performa was used for each patient which recorded multiple variables including demographics (age and sex), involved side (right or left), type (mesioangular, distoangular, horizontal, vertical and others) and pattern (Class 1, 2, 3 and Position A, B, C).

\subsection{Assessment of variables}

Assessment of variables was done with the help of detailed history, clinical examination and radiographic examination. IOPAR AND wherever necessary, Orthopantomographs (OPG) were employed for radiographic analysis, which was performed by a single examiner, in a dark room to avoid interpersonnel errors. Statistical analysis was performed using Statistical Package for Social Sciences (SPSS) version 17.0. Winter's classification (Table 1) was used for determining the type of impaction while Pell and Gregory's classification (Table 2) was used for calculating the pattern.

Table 1: Winter's Classification (Based on Angulation between the Long Axis of M2 and M3)

\begin{tabular}{|c|c|c|}
\hline $\begin{array}{l}\text { Impaction } \\
\text { pattern }\end{array}$ & $\begin{array}{l}\text { Relationship between M3 } \\
\text { and M2 }\end{array}$ & $\begin{array}{l}\text { Angle formed between } \\
\text { long axis of M3 and M2 } \\
\text { (in degrees) }\end{array}$ \\
\hline Mesioangular & $\begin{array}{l}\text { M3 is mesially tilted to- } \\
\text { wards M2 } \\
\text { Intersection of their long } \\
\text { axis makes an acute angle }\end{array}$ & 11 to 79 \\
\hline Horizontal & $\begin{array}{l}\text { An exaggerated mesial } \\
\text { inclination of M3 } \\
\text { Occlusal surface of M3 } \\
\text { faces the distal side of M2 }\end{array}$ & 80 to 100 \\
\hline Vertical & $\begin{array}{l}\text { Long axis of M3 and M2 } \\
\text { run parallel } \\
\text { Both M3 and M2 have simi- } \\
\text { lar inclination }\end{array}$ & 10 to -10 \\
\hline Distoangular & $\begin{array}{l}\text { M3 is inclined distally, } \\
\text { away from M2 } \\
\text { Intersection of their long } \\
\text { axis makes an obtuse angle }\end{array}$ & -11 to -79 \\
\hline Others & $\begin{array}{l}\text { Inclination of M3 is greater } \\
\text { than that of the horizontal } \\
\text { impaction. } \\
\text { Inverted impaction belongs } \\
\text { to this category }\end{array}$ & 111 to -80 \\
\hline
\end{tabular}

\section{Results}

A total of 150 patients having 228 mandibular impacted third molars were included this study. Their ages ranged from $21-43$ years with a mean age of 26.6 years. Patients of age group $21-25$ years showed the highest number of impactions (49.4\%) with 4145 age group showing lowest number $(1.3 \%)$ (Table 3$)$. There was a gradual decline in the number of patients with increase in age (Fig.1). Males exhibited a higher prevalence with 81 cases $(54 \%)$ when compared to females, with 69 cases $(46 \%)$. The male to female ratio was 1.2:1. Apart from that, right side was shown to have predilection $(53 \%)$.
Table 2: Pell and Gregory Classification (Based on Relation with Mandibular Ramus \& M2)

\begin{tabular}{|c|c|}
\hline Class & $\begin{array}{l}\text { Relationship of M3 to the anterior border of ramus of mandi- } \\
\text { ble }\end{array}$ \\
\hline \multirow[t]{3}{*}{ Class 1} & $\begin{array}{l}\text { Mesiodistal diameter of M3 completely anterior to the anterior } \\
\text { border of ramus. }\end{array}$ \\
\hline & Best likelihood for normal eruption. \\
\hline & $\begin{array}{l}\text { Approximately half mesiodistal diameter of M3 is covered by } \\
\text { ramus of mandible. }\end{array}$ \\
\hline Class 2 & $\begin{array}{l}\text { Distal aspect covered by bone and soft tissue gives way for } \\
\text { food lodgement and resultantly enhances susceptibility to } \\
\text { caries and periodontitis. }\end{array}$ \\
\hline \multirow{3}{*}{ Class 3} & M3 located completely within the ramus of mandible. \\
\hline & Least accessible. \\
\hline & Most difficult to remove. \\
\hline Position & $\begin{array}{l}\text { Relationship of occlusal surface of M3 to the occlusal plane of } \\
\text { M2 }\end{array}$ \\
\hline $\begin{array}{l}\text { Position } \\
\text { A }\end{array}$ & At the same level \\
\hline $\begin{array}{l}\text { Position } \\
\text { B }\end{array}$ & Between the occlusal plane and cervical line of M2 \\
\hline $\begin{array}{l}\text { Position } \\
\text { C }\end{array}$ & Below the cervical line of M2 \\
\hline
\end{tabular}

Table 3: Distribution of Impacted M3 among Various Age Groups

\begin{tabular}{lll}
\hline Age groups & Number & $\%$ age \\
\hline 21-25 years & 74 & 49.40 \\
26-30 years & 46 & 30.70 \\
31-35 years & 21 & 14.00 \\
36-40 years & 07 & 04.70 \\
$41-45$ years & 02 & 01.30 \\
Total & 150 & 100.00 \\
\hline
\end{tabular}

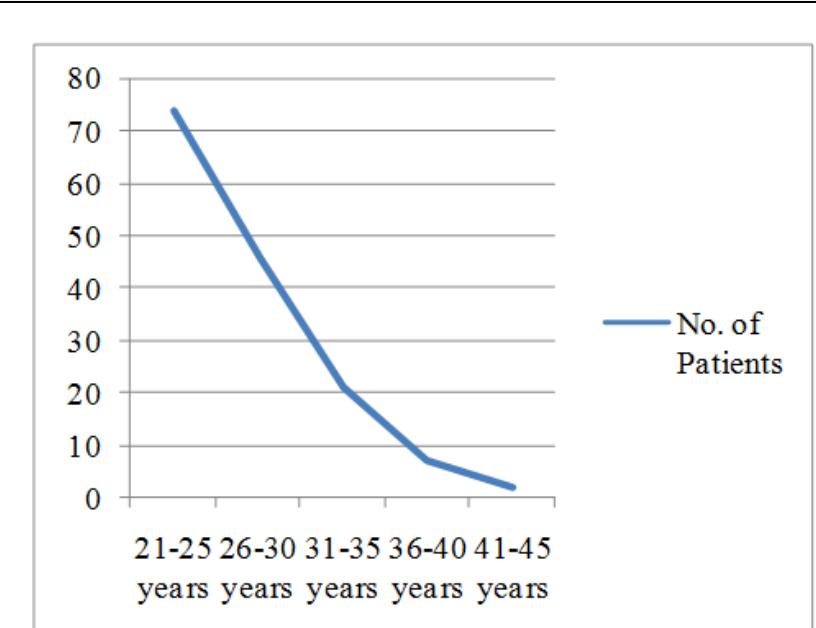

Fig. 1: Declining Trend of Mandibular M3 Impaction with Increase in Age.

The distribution of angulation of impacted mandibular M3 was determined using winter's classification, which showed that mesioangular was the most frequently occurring type $(45.2 \%)$ followed by vertical $(22.8 \%)$, distoangular $(18.8 \%)$ and horizontal $(11.4 \%)$ (Fig. 2). Pell and Gregory method showed higher frequency of impacted mandibular M3 with class 2 ramus relationship and position A depth $(29.4 \%)$, while class 1 ramus relationship and position $\mathrm{C}$ was found least frequently (1.3\%) (Fig. 3). 


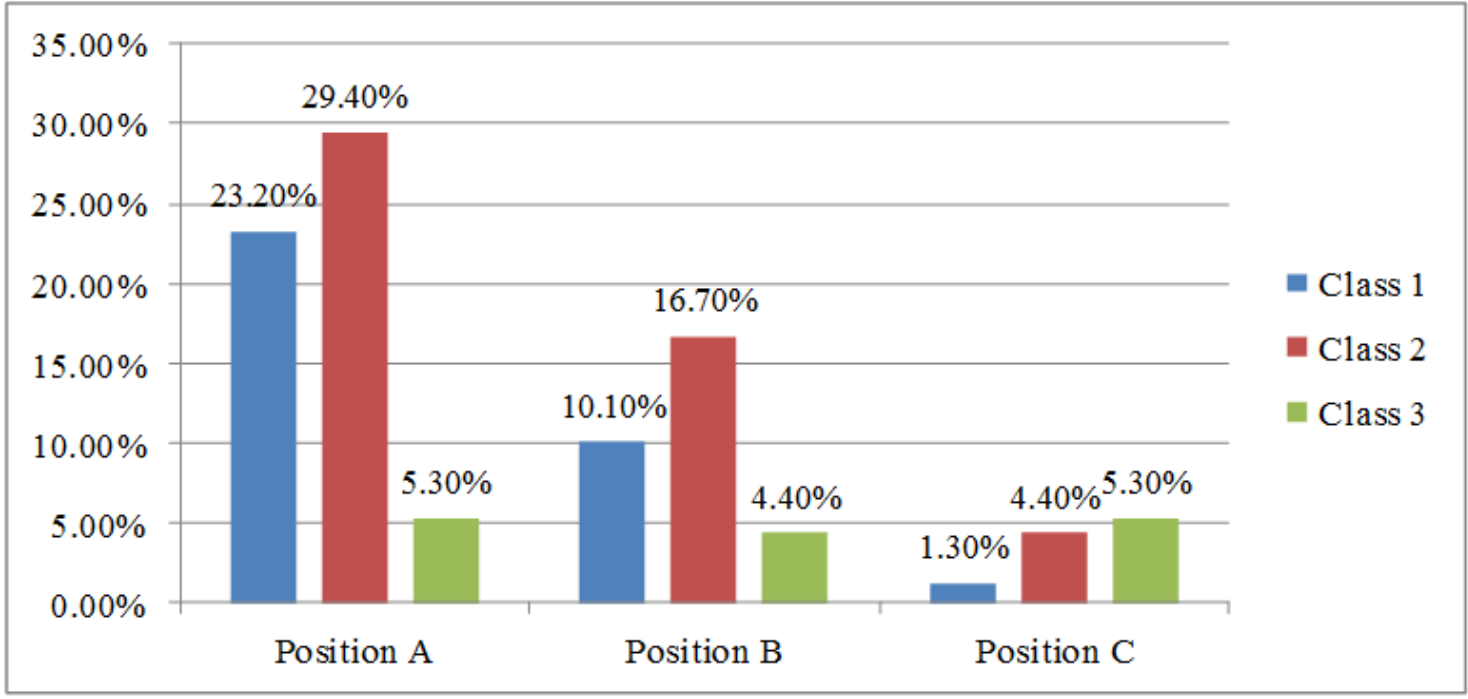

Fig. 2: Distribution of Ramus Relationship and Depth Using Pell and Gregory Method.

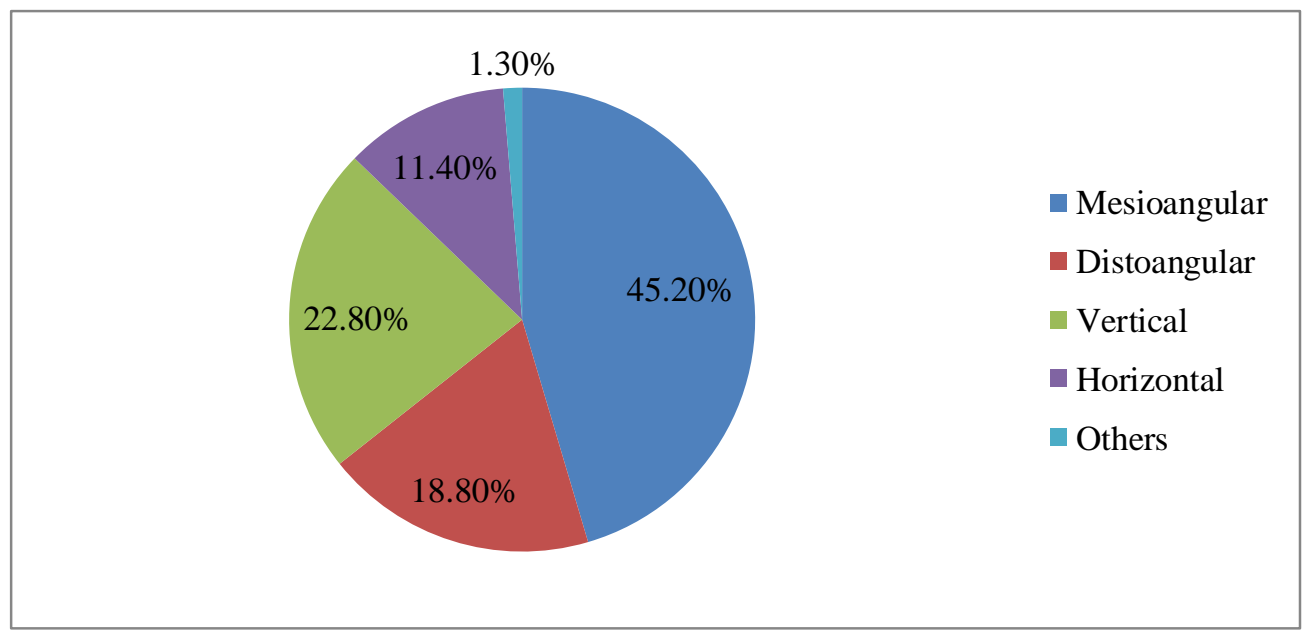

Fig. 3: Distribution of Angulation Patterns Using Winter's Classification

\section{Discussion}

The minimum age of patients to be selected in this study was kept 20 years, the reason being that growth of the jaws is basically completed by the age of 17 years [Almpani \& Kolokitha 2015], and therefore at the age of 20 , it is possible to distinguish whether a third molar is in normal eruptive process or will remain impacted in the jaw. Further, it has been suggested that 20-25 years is the most suitable age for studying the frequency and pattern of third molar impaction [Quek et al. 2003]. The age of patients in our study ranged from 21-43 years with a mean age of 26.6 years. Results showed $49.3 \%$ prevalence in $21-25$ age group and $30.7 \%$ prevalence in 26-30 years age group. These findings were in correlation with local and international studies [Ishfaq 2006, Blondeau 2007]. It also implicated that the problems concerning M3 impaction affect people in the same age period in different populations. A declining trend was seen in the fourth and fifth decade which may be linked to the early removal of impacted third molars, completion of eruption or disappearance of complaints. This corroborates the assertion that the period between 20 and 40 years of age may be considered the most active years for third molar removal [Gbotolorun et al. 2007].

The study findings revealed a higher frequency of mandibular M3 impaction in males (54\%) as compared to females (46\%) which are in close correlation to a Kenya study reporting male predominance with a male to the female ratio of 7:5 [Mwaniki \& Guthua 1996], and another similar study conducted in U.S.A reporting 57\% male patients [Bui et al. 2003]. However, litreature supports multiple studies, Montelius [Kumar Pillai et al. 2014], Hazza et al. [Hazza et al. 2006], Gupta et al. [Gupta et al. 2011] and Padhye et at. [Padhye et al. 2013], which reported insignificant sexual predilection. Although, some observed higher frequency in white european females [Lytle 1995] and Singapore Chinese females than males [Peterson et al. 1998]. Female predilection can be explained with Hellman's statement who proposed that the jaws in females stop growing at the time when third molars begin to erupt, whereas in males, the growth continues beyond the time of third molar eruption [Sandhu \& Kaur 2005].

Assessment of angulation of impacted mandibular M3 was performed with Winter's classification, which observed Mesioangular impaction as the most common type of impaction (45.2\%), followed by vertical $(22.8 \%)$, distoangular $(18.8 \%)$, horizontal $(11.4 \%)$ and others (1.3\%). With regard to mesioangular type, our observations were found in close range with studies of Gbotolorun [Gbotolorun et al. 2007] (50\%), Quek et al. [Quek et al.2003] $(60 \%)$ and Kruger et al. [Kruger et al. 2001] (62.9\%), but higher in proportion than that obtained by Byahatti and Ingafou [Byahatti \& Ingafou 2012] (23.7\%). In our study, mesioangular impaction was the most common angular position followed by vertical and distoangular, similar to the result obtained by Hattab et al. [Hattab et al. 1995] Higher prevalence of mesioangular impaction might be related to the developmental position of its primordial germ, found high up in the mandibular ramus with its occlusal surface slanting mesially or sometimes, horizontally, and the developing crown then moves in response to postural change in the mandible induced by growth. Cessation of jaw growth before complete uprighting of the crown will most likely trap the developing tooth in 
a mesio-angular position. [Kruger et al. 2001]. Few studies report vertical as the most common angulation type followed by mesioangular [Bataineh 2002, Almendros-Marques 2006].

Pell and Gregory method was used to determine the ramus relationship and depth of impaction, and showed that Class 2 position A was most frequently found $(29.30 \%)$ pattern while Class 1 Position $\mathrm{C}$ least frequent $(1.30 \%)$. These findings are supported by national and international studies [Sheikh 2012, Msagati 2013 , Padhye 2013, Syed 2013, Hupp 2014]. Additionally, Hattab et al [Hattab et al. 1995] (58\%) and Gupta et al. [Gupta et al. 2011] (61.8\%) also found Position A impaction to be more common. Similar study of Gupta et al. [Gupta et al. 2011] and Padhye et al. [Padhye et al. 2013] reported a predominance of Class II. The presence of adequate mesiodistal space between the distal surface of the second molar and the ascending ramus is a predictable factor for the eruptive process. Lucchese and Manuelli [Lucchese \& Manuelli 2003] found that space behind second molar was reduced in $90 \%$ of cases present with mandibular third molar impaction. However, inadequate mesiodistal crown width cannot be attributed as the sole aetiological factor for abortive third molar eruption. The findings of our study are also common with Malaysian [Jaffar \& Tin 2009], Nigerian [Obiechina et al. 2001] and Italian [Monaco et al. 2004] studies which present Class IIA as the most common pattern of impaction with exception to Spanish population showing Class IIB as the predominant position [Almendros-Marques et al. 2006]

\section{Conclusion}

This article can be concluded:

- Patients in their third decade of age showed higher frequency of lower M3 impaction.

- Males were found to have a predilection

- Right side was more commonly involved

- Mesioangular type was most prevalent followed by vertical, distoangular and horizontal types

- Class 2 Position A was most frequent pattern and Class 1 Position $\mathrm{C}$ least frequent.

Procedural complexity and resultant morbidity necessitate complete evaluation of position, angulation and bone overlying third molar to construct best possible surgical approach. Despite all assessments, it is sole responsibility of surgeon to make appropriate decisions.

\section{Acknowledgement}

I would like to appreciate the clinic authorities for their approval to conduct this study and the patients for their consent.

\section{References}

[1] Agarwal KN, Gupta R, Faridi MM \& Kalra N (2004) Permanent dentition in Delhi boys of age 5-14 years. Indian Pediatr 41, 1031-5.

[2] Almendros-Marqués N, Alaejos-Algarra E, Quinteros-Borgarel-lo M, Berini-Aytés L \& Gay-Escoda C (2008) Factors influencing the pro $\neg$ phylactic removal of asymptomatic impacted lower third molars. $\begin{array}{lllll}\text { Int } \mathbf{J} & \text { Oral } & \text { Maxillofac } & \text { Surg } & 37,35\end{array}$ http://dx.doi.org/10.1016/j.ijom.2007.06.008.

[3] Almpani K \& Kolokitha OE (2015) Role of third molars in orthodontics. World J Clin Cases 3, 132-40. http://dx.doi.org/10.12998/wjcc.v3.i2.132.

[4] Almendros-Marques N, Berini- Aytes L \& Gay-Escoda C (2006) Influence of lower third molar position on the incidence of preoperative complications. Oral Surg Oral Med Oral Pathol Oral Radoil Endod 102, 725-32. http://dx.doi.org/10.1016/j.tripleo.2006.01.006

[5] Bataineh AB, Albashaireh ZS \& Hazza'a AM (2002) the surgical removal of mandibular third molars: a study in decision making. Quintessence Int 33, 613-7.

[6] Blondeau F \& Daniel NG (2007) Extraction of impacted mandibular third molars: postoperative complications and their risk factors. J Can Dent Assoc 73, 325a-e.
[7] Bui CH, Seldin EB \& Dodson TB (2003) Types, frequencies, and risk factors for complications after third molar extraction. J Oral Maxillofac Surg 61, 1379-89. http://dx.doi.org/10.1016/j.joms.2003.04.001.

[8] Byahatti S \& Ingafou MS (2012) Prevalence of eruption status of third molars in Libyan students. Dent Res J 9, 152-7. http://dx.doi.org/10.4103/1735-3327.95228.

[9] Gbotolorun MO, Arotiba GT \& Ladeinde AL (2007) Assessment of factors associated with surgical difficulty in impacted mandibular third molar extraction. J Oral Maxillofac Surg 65, 1977-1983 http://dx.doi.org/10.1016/j.joms.2006.11.030.

[10]Gupta S, Bhowate RR, Nigam N \& Saxena S (2011) Evaluation of impacted mandibular third molar by panoramic radiography. ISNR Dent 2011, 406714. http://dx.doi.org/10.5402/2011/406714.

[11] Hattab FN, Fahmy MS \& Rawashedeh MA (1995) Impaction status of third molars in Jordanian students. Oral Surg Oral Med Oral Pathol Radiol Endod 79, 24-9. http://dx.doi.org/10.1016/S10792104(05)80068-X.

[12] Hazza'a AM, Albashaireh ZS \& Bataineh A (2006) the relationship of the inferior dental canal to the roots of impacted mandibular third molars in a Jordanian population. J Contemp Dent Pract 7, 71-8.

[13]Hupp JR, Ellis III E \& Tucker MR (2008) Contemporary oral and maxillofacial surgery. Mosby Elsevier, St. Louis, Missouri.

[14]Hupp JR, Ellis III E \& Tucker MR (2014) Principles of management of impacted teeth. In Contemporary Oral and Maxillofacial Surgery (Hupp JR, Ellis III E \& Tucker MR Eds.), Elsevier Publishers, Philadelphia, pp. 143-67. http://dx.doi.org/10.1016/b978-0-323-091770.00009-8.

[15] Ishfaq M, Wahid A, Rahim AU \& Munim A (2006) Patterns and presentations of impacted mandibular third molars subjected to removal at Khyber College of Dentistry Peshawar. Pak Oral Dent J 26, 221-6.

[16]Jaffar RO \& Tin MM (2009) Impacted mandibular third molars among patients attending Hospital Universiti Sains Malaysia. Archives of Orofacial Sciences 4, 712

[17] Kaya GS, Aslan M, Ömezli MM \& Dayi E (2010) some morphological feaᄀtures related to mandibular third molar impaction. J Clin Exp Dent 2, e12-e7. http://dx.doi.org/10.4317/jced.2.e12.

[18] Kruger E, Thomson WM \& Konthasinghe P (2001) Third molar outcomes from age 18 to 26: findings from a population-based New Zealand longitudinal study. Oral Surg Oral Med Oral Pathol Oral Radio Endod 92, 150-5. http://dx.doi.org/10.1067/moe.2001.115461.

[19] Kumar Pillai A, Thomas S, Paul G, Singh SK \& Moghe S (2014) Incidence of impacted third molars: a radiographic study in People's hospital, Bhopal, India. J Oral Biol Craniofac Res 4, 76-81. http://dx.doi.org/10.1016/j.jobcr.2014.04.001.

[20]Lucchese a \& Manuelli M (2003) Prognosis of third molar eruption: a comparison of three predictive methods. Prog Orthod 4, 4-19.

[21]Lytle JJ (1995) Etiology and indications for the management of impacted teeth. Northwest Dent 74, 23-32.

[22]Meisami T, Sojat A, Sàndor GKB, Lawrence HP \& Clokie CML (2002) Impacted third molars and risk of angle fracture. Int J Oral $\begin{array}{llll}\text { Maxillofac Surg } & 31, & 140-144 .\end{array}$ http://dx.doi.org/10.1054/ijom.2001.0215.

[23] Monaco G, Montevecchi M, Bonetti GA, Gatto MR \& Checchi L (2004) Reliability of panoramic radiography in evaluating the topographic relationship between the mandibular canal and impacted third molars. J Am Dent Assoc 135, 312-8. http://dx.doi.org/10.14219/jada.archive.2004.0179.

[24] Msagati F, Simon ENM \& Owibingire S (2013) Pattern of occurrence and treatment of impacted teeth at the Muhimbili National Hospital, Dar es Salaam, Tanzania. BMC Oral Health 13, 1-6. http://dx.doi.org/10.1186/1472-6831-13-37.

[25] Mwaniki D \& Guthua SW (1996) Incidence of impacted mandibular third molars among dental patients in Nairobi, Kenya. Tropical Dental Journal 19, 17-9.

[26]Obiechina AE, Arotiba JT \& Fasola AO (2001) Third molar impaction: evaluation of the symptoms and pattern of impaction of mandibular third molar teeth in Nigerians. Odontostomatol Trop 24, 22-5.

[27]Padhye MN, Dabir AV, Girotra CS \& Pandhi VH (2013) Pattern of mandibular third molar impaction in the Indian population: a retrospective clinico-radiographic survey. Oral Surg Oral Med Oral Pathol Oral Radiol 116, 161-6. http://dx.doi.org/10.1016/j.oooo.2011.12.019.

[28]Pell GJ \& Gregory BT (1933) Impacted mandibular third molars: classification and modified techniques for removal. Dent Digest 39 330-338.

[29]Peterson LJ, Ellis III E, Hupp JR \& Tucker MR (1998) Contemporary Oral and Maxillofacial Surgery. Mosby, St. Louis.

[30]Quek SL, Tay CK, Tay KH, Toh SL \& Lim KC (2003) Pattern of third molar impaction in a Singapore Chinese population: a retrospec- 
tive radiographic survey. Int $\mathrm{J}$ Oral Maxillafac Surg 32, 548-52. http://dx.doi.org/10.1016/S0901-5027(03)90413-9.

[31]Sandhu S \& Kaur T (2005) Radiographic evaluation of the status of third molars in the Asian-Indian students. J Oral Maxillofac Surg 63, 640-5. http://dx.doi.org/10.1016/j.joms.2004.12.014.

[32] Sheikh MA, Riaz M \& Shafiq S (2012) Incidence of distal caries in mandibular second molars due to impacted third molars - A clinical \& radiographic study. Pakistan Oral \& Dent J 32, 364-70.

[33] Syed KB, Kota Z, Ibrahim M, Bagi MA \& Assiri MA (2013) Prevalence of impacted molar teeth among Saudi population in Asir region, Saudi Arabia a retrospective study of 3 years. J Int Oral Health 5, 43-7.

[34]Winter GB (1926) the Principles of Exodontia as Applied to the Impacted Third Molar. American Medical Book Co, St. Louis. 